\title{
Correction to: Evaluation of endoscopic ultrasoundguided gastric botulinum toxin injections in the treatment of obesity
}

Asmaa Gameel ${ }^{1}$, Monir Bahgat ${ }^{1}$, Seham Seif ${ }^{1}$, Maha Habeeb ${ }^{1}$, Mohammed Abd El-Ghany ${ }^{2}$ and Ahmed Youssef Altonbary ${ }^{1 *}$

\section{Correction to: Egypt J Intern Med (2020) 32:29 \\ https://doi.org/10.1186/s43162-020-00027-8}

Following the publication of the original article [1], the authors brought to our attention that the > (greater than) sign was inadvertently used instead of the < (less than) sign for the $p$ value in the Abstract, Methods and Figure 4 legend.

The correct $p$ value is less than $0.001(<0.001)$ and not more than $0.001(>0.001)$ as initially reported, something that has now been corrected in the original article [1].

\footnotetext{
Author details

${ }^{1}$ Department of Gastroenterology and Hepatology, Mansoura Specialized Medical Hospital, Mansoura University, Mansoura 35516, Egypt. ²Department of Endocrinology and Metabolism, Mansoura Specialized Medical Hospital,

Mansoura University, Mansoura, Egypt.
}

Published online: 25 January 2021

\section{Reference}

1. Gameel A et al (2020) Evaluation of endoscopic ultrasoundguided gastric botulinum toxin injections in the treatment of obesity. Egypt J Intern Med 32:29 https://doi.org/10.1186/s43162-020-00027-8

\footnotetext{
The original article can be found online at https://doi.org/10.1186/s43162020-00027-8

* Correspondence: a.tonbary@gmail.com

${ }^{1}$ Department of Gastroenterology and Hepatology, Mansoura Specialized

Medical Hospital, Mansoura University, Mansoura 35516, Egypt
}

Full list of author information is available at the end of the article

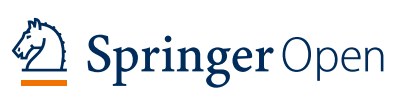

(c) The Author(s). 2021 Open Access This article is licensed under a Creative Commons Attribution 4.0 International License which permits use, sharing, adaptation, distribution and reproduction in any medium or format, as long as you give appropriate credit to the original author(s) and the source, provide a link to the Creative Commons licence, and indicate if changes were made. The images or other third party material in this article are included in the article's Creative Commons licence, unless indicated otherwise in a credit line to the material. If material is not included in the article's Creative Commons licence and your intended use is not permitted by statutory regulation or exceeds the permitted use, you will need to obtain permission directly from the copyright holder. To view a copy of this licence, visit http://creativecommons.org/licenses/by/4.0/. 